\title{
Maternal undernutrition during late pregnancy in sheep. Its relationship to maternal condition, gestation length, hepatic physiology and glucose metabolism
}

\author{
BY HILARY J. WEST \\ Department of Veterinary Clinical Science and Animal Husbandry, University of Liverpool \\ Veterinary Field Station, Leahurst, Chester High Road, Neston, South Wirral L64 7TE
}

(Received 13 March 1995 - Revised 26 July 1995-Accepted 8 August 1995)

\begin{abstract}
There is a paucity of information on the metabolic effects of undernutrition of the ewe carrying multiple fetuses in late pregnancy. In the present study the effects of induction of ketosis from $132 \mathrm{~d}$ gestation in ewes carrying twin fetuses were compared with a control group. The ewes were well fed up to $132 \mathrm{~d}$. Ketotic ewes showed a loss of condition score from 3.7 (SE 0.11) at 130 d gestation to 3.0 (SE 0.15) $10 \mathrm{~d}$ later after clinical recovery, compared with control twin-pregnant ewes $(P<0.01)$. The weight loss during the same time period was from 70.6 (SE 2.7 ) $\mathrm{kg}$ at $130 \mathrm{~d}$ to 64.2 (SE 2.7) $\mathrm{kg}$ at $140 \mathrm{~d}$ gestation. As expected, both groups lost weight and condition score in the first $28 \mathrm{~d}$ of lactation. Induction of ketosis caused a significant shortening of the gestation period to 142.8 (SE 0.7 ) d compared with 150 (SE 0.4) d in normal twin-pregnant ewes $(P<0.001)$. Ewes with induced ketosis recovered clinically and showed a normal feed intake by 3.4 (SE 0.07 ) d; three required treatment. Induction of ketosis resulted in reduction of hepatic uptake of bromosulphthalein $(P<0.01)$ and its biliary excretion $(P<0.05)$, metabolic clearance rate $(P<0.001)$, fractional clearance $(P<0.001)$ and 15 and 30 min retention compared with control twin-pregnant ewes. Most values had returned to normal by the first week of lactation. It is thought that in human pregnancy similar changes in bromosulphthalein clearance may be related to reduced binding sites for bromosulphthalein in the liver caused by increased circulating oestrogens. Induction of ketosis resulted in a significant hypoglycaemic $(P<0.01)$, ketotic $(P<0.001)$ state compared with well-fed twin-pregnant ewes. These changes could be correlated with the severity of the clinical signs, together with a significant rise in plasma urea $(P<0.001)$ and $\mathrm{NH}_{3}(P<0.05)$ concentrations. Again, the return of most of these values to normal by the first week of lactation lends support to the reversibility of hepatic lesions caused by fatty infiltration of the liver. The severity of this condition in naturally occurring cases suggests that factors other than undernutrition may be contributory, such as the general body condition of the ewe and glucose metabolism by the liver, including the conversion of propionate to glucose.
\end{abstract}

Ketosis: Pregnancy: Liver function: Sheep

Pregnancy toxaemia is a disorder of the metabolism of ewes in advanced pregnancy and most likely to occur when there is an inadequate supply of glucose from the metabolism of dietary carbohydrate (Krebs, 1966; Mellor, 1983). This results in increased gluconeogenesis in the liver which causes a parallel rise in ketone-body formation above what can be oxidized and leads to clinical ketosis. Pregnancy toxaemia can occur in ewes with twins, triplets or even with one large single lamb (Kronfeld, 1972) and hypoglycaemia becomes superimposed on ketosis. In general, the results of treatment are often disappointing and variable, with a high maternal mortality rate (Ranaweera et al. 1979). The body reserves of the ewe and the timing and severity of the period of undernutrition may be the reason for the difference in responses of individual ewes to treatment.

Ruminants absorb only small amounts of glucose from the alimentary tract, relying on 
hepatic gluconeogenesis for much of their glucose supply. Propionate is the chief precursor in fed animals, arising primarily from microbial fermentation in the rumen (Bergman et al. 1966). The rate of glucose synthesis is highest in fed animals, decreasing during fasting. Liver cells from fed sheep have a very high capacity for propionate utilization and conversion into glucose (Demigné et al. 1991). Propionate may alter the rate of various metabolic pathways, especially ureogenesis or ketogenesis (Rattenbury et al. 1983). Glucose is transported across the placenta by a membrane-bound carrier mechanism (Stacey et al. 1978) as are some amino acids (Lemons et al. 1976). Hence a deficiency of metabolites will affect fetal growth.

There have been few studies on the effects of the fatty liver found in ewes with pregnancy toxaemia on hepatic function (Katz \& Bergman, 1966; Wierda et al. 1985). Bromosulphthalein (BSP) is rapidly taken up by the liver cells, conjugated and excreted into the bile and is suitable for evaluating liver function in conscious animals, as it is non-invasive and repeatable (West, 1989). It is likely to be a reliable indicator of changes in the liver compared with enzymes such as iditol (EC 1.1.1.14) and glutamate dehydrogenase $(E C 1.4 .1 .2)$ that are often released in the acute phase of a disease and indicate liver damage rather than altered liver function (Wierda et al. 1985).

To address this, and to investigate further the effects of undernutrition in late pregnancy in the ewe, the present study was carried out on twin-pregnant ewes. Induced ketosis was studied with the aim of investigating its effects on gestation length, body weight and condition score of the ewe and its effect on hepatic physiology during the clinical stage and recovery phase, which provided a useful model for the study of pregnancy toxaemia in ewes.

\section{MATERIALS AND METHODS}

\section{Animals and management}

Two groups of twelve 3-5-year-old pregnant Clun Forest ewes from a total group of twenty-eight with oestrous cycles synchronized with medroxyprogesterone acetate (Veramix, Upjohn Ltd, Crawley, W. Sussex) were studied. During pregnancy they were maintained at pasture and supplemented with hay and concentrates, to allow a steady increase in body weight. Exact service dates were known and ewes were radiographed between the 100th and 110th d of pregnancy, in order to select animals with twin fetuses.

Ewes, which were accustomed to handling, were brought in from pasture at $100 \mathrm{~d}$ gestation and housed in individual pens in the same room (15-20 ). They were fed $a d$ lib. on hay of $11 \mathrm{MJ}$ metabolizable energy (ME) $/ \mathrm{kg} \mathrm{DM}$ and $13.2 \mathrm{~g} \mathrm{~N} / \mathrm{kg} \mathrm{DM}$ plus $0.5 \mathrm{~kg}$ concentrate/d at 2 months gestation, increasing gradually up to $1 \mathrm{~kg} / \mathrm{d}$ per head for the last 6 weeks of pregnancy and up to $1.5 \mathrm{~kg} / \mathrm{d}$ by the fourth week of lactation; fresh water was freely available. The concentrate used was a mixture of barley, soyabean meal, fishmeal and products of sugar production, and was given morning and evening.

Ewes in each mating group were allocated randomly to one of the two treatment groups on housing and were weighed and condition was scored by feeling the midlumbar region (Clarkson \& Faull, 1990; McCrabb et al. 1991). The level of feed was calculated (Ministry of Agriculture, Fisheries and Food, 1984) to support a gain of approximately $30 \mathrm{~g} / \mathrm{d}$ between 30 and $100 \mathrm{~d}$ gestation as follows: for a $70 \mathrm{~kg}$ ewe at $100 \mathrm{~d}$ gestation the $\mathrm{ME}$ allowance was $0.42 \mathrm{MJ} / \mathrm{kg}$ metabolic weight $\left(\mathrm{W}^{0.75}\right.$ ) plus $0.37 \mathrm{MJ} / \mathrm{kg}$ lamb birthweight with $93 \mathrm{~g}$ crude protein $/ \mathrm{kg}, 2.5 \mathrm{~g} \mathrm{Ca} / \mathrm{kg}$ and $2 \mathrm{~g} \mathrm{P} / \mathrm{kg}$. This increased to an allowance of $0.42 \mathrm{MJ} / \mathrm{kg} \mathrm{W}^{0.75} \mathrm{ME}$ plus $0.90 \mathrm{MJ} / \mathrm{kg}$ lamb birth weight with $113 \mathrm{~g}$ crude protein $/ \mathrm{kg}$, $4 \mathrm{~g} \mathrm{Ca} / \mathrm{kg}$ and $2.4 \mathrm{~g} \mathrm{P} / \mathrm{kg}$ for $70 \mathrm{~kg}$ control ewes by the last 2 weeks of gestation, supporting a weight gain of approximately $225 \mathrm{~g} / \mathrm{d}$.

During the first 4 weeks of lactation the allowance for a $70 \mathrm{~kg}$ ewe was $0.42 \mathrm{MJ} / \mathrm{kg} \mathrm{W}^{0.75}$ 


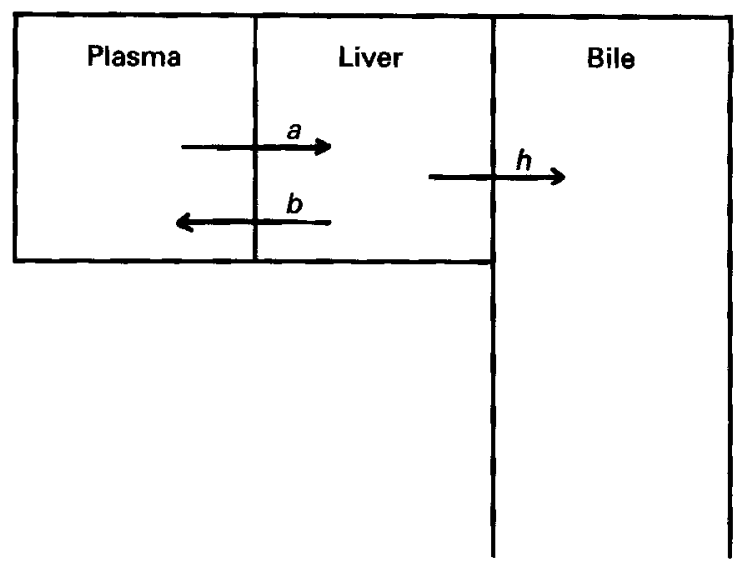

Fig. 1. The three-compartment model for bromosulphthalein uptake by the liver from plasma, $a$, its excretion from the liver into bile, $h$ and its reflux from liver to plasma, $b, a, h$ and $b$ are proportionality transfer constants.

maintenance and $4.5 \mathrm{MJ} / \mathrm{kg}$ milk production, with $150 \mathrm{~g}$ crude protein $/ \mathrm{kg}, 3.9 \mathrm{~g} \mathrm{Ca} / \mathrm{kg}$ and $2.9 \mathrm{~g} \mathrm{P} / \mathrm{kg}$. Animals were treated regularly for internal parasites with laevamisole hydrochloride (Nilverm Gold, Mallinkrodt, Crewe, Cheshire).

\section{Induction of ketosis}

Ketosis was induced at $132 \mathrm{~d}$ pregnancy, by allowing access to drinking water only for periods of up to $4 \mathrm{~d}$, to produce typical clinical signs of pregnancy toxaemia, i.e. partial or complete loss of vision and eye preservation reflex, opisthotonus, muscle tremors and staggering gait, as described by Ranaweera et al. (1979). At the stage at which ketosis was induced and these clinical signs were observed, feed was reintroduced in normal amounts, using the same diet as described for control ewes.

\section{Bromosulphthalein clearance studies}

BSP clearance studies were carried out on treatment and control twin-pregnant ewes at $120 \mathrm{~d}$ gestation, with $6 \mathrm{mg} \mathrm{BSP} / \mathrm{kg}$ by a single intravenous injection, then at weekly intervals on induction of ketosis, at clinical recovery until the first week of lactation, and again at the fourth week of lactation, as described by West (1989). The proportionality transfer constants for uptake of BSP by the liver cell from plasma $(a)$, for excretion of BSP from liver cell to bile $(h)$, and for the rate per unit liver load at which a proportion of BSP passes back from liver to plasma $(b)$, were calculated as described previously (West, 1989) (Fig. 1). The fractional clearance $(k ;(/ \mathrm{min}), 15$ and $30 \mathrm{~min}$ retentions $(\%)$ and metabolic clearance rate $(\mathrm{ml} / \mathrm{min}$ per $\mathrm{kg})$ were also measured.

\section{Clinical chemistry}

Plasma glucose concentration was determined on oxalate fluoride samples by the guaiacum and glucose oxidase (EC 1.1.3.4) method (Morley et al. 1968). The method of Bakker \& White (1957) as modified by Ford \& Boyd (1960) was used to determine total ketone bodies (aceto-acetate, $\beta$-hydroxybutyrate and acetone) in plasma. Plasma urea concentration was measured (Fawcett \& Scott, 1960) using the Boehringer Mannheim test (124788) combination (Boehringer Mannheim, Bracknell, Berks).

Plasma $\mathrm{NH}_{3}$ concentration was determined immediately on collection and storage on ice using EDTA plasma (Da Fonseca-Wollheim, 1973) and the Boehringer Mannheim test kit 125857. 
Table 1. Condition scoret of control and ketotic ewes during late pregnancy and early lactation $\ddagger$

(Mean values with their standard errors)

\begin{tabular}{|c|c|c|c|c|c|c|c|}
\hline & \multicolumn{3}{|c|}{ Control } & \multicolumn{3}{|c|}{ Ketotic } & \multirow{2}{*}{$\begin{array}{c}\text { Statistical } \\
\text { significance }\end{array}$} \\
\hline & $n$ & Mean & SE & $n$ & Mean & SE & \\
\hline \multicolumn{8}{|c|}{ Day of pregnancy } \\
\hline 110 & 12 & $3 \cdot 6$ & 0.09 & 12 & $3 \cdot 6$ & $0 \cdot 10$ & NS \\
\hline 130 & 12 & $3 \cdot 6$ & $0 \cdot 10$ & 12 & $3 \cdot 7$ & $0 \cdot 11$ & NS \\
\hline 140 & 12 & $3 \cdot 5$ & 0.11 & 12 & $3 \cdot 0$ & $0 \cdot 15$ & $* *$ \\
\hline \multicolumn{8}{|c|}{ Day of lactation } \\
\hline 7 & 12 & $3 \cdot 1$ & $0 \cdot 16$ & 11 & $2 \cdot 8$ & $0 \cdot 17$ & $*$ \\
\hline 28 & 12 & $3 \cdot 2$ & $0 \cdot 14$ & 11 & $2 \cdot 7$ & $0 \cdot 12$ & $*$ \\
\hline
\end{tabular}

Statistical significance between group means: ${ }^{*} P<0.05,{ }^{* *} P<0.01$.

$\dagger$ Condition scores range from 1 to 5 (normal range $2-4$ ).

$\ddagger$ Ketosis was induced on day 132 and therefore measurements on days 110 and 130 were control measurements before the onset of treatment.

Clinical chemistry measurements were performed twice weekly during the period of study, and samples were collected after the morning feed. Samples, where possible, were analysed immediately in the case of plasma $\mathrm{NH}_{3}$ or, if not, plasma was stored at $-20^{\circ}$ until analysis.

\section{Statistical analysis}

One-way ANOVA was used to test statistical differences between the treatment and control groups, using the statistical package SPSSX (Nie, 1983). A Student's $t$ test was applied to paired data in the analysis of live weight.

\section{RESULTS}

\section{Live weight and condition scores}

The condition scores of control and ketotic ewes during late gestation and early lactation are shown in Table 1. Both groups of ewes lost condition in early lactation, as was expected, but the ketotic ewes lost condition score at $140 \mathrm{~d}$ gestation $(P<0.01)$ and at 7 and $28 \mathrm{~d}$ lactation $(P<0.05)$ at a significantly greater rate than control ewes when the means were compared. This was correlated with similar changes in liveweight (Table 2). The average weight loss was $4-10 \mathrm{~kg}$ between induction and development of ketosis.

\section{Induction of ketosis}

Induction of ketosis caused a significant shortening of the gestation period $(P<0.001)$ between normal twin-pregnant ewes of 150 (SE 0.4) d and pregnant, hypoglycaemic, ketotic ewes of 142.8 (SE 0.7) d (Table 3).

The hypoglycaemic ketosis produced in ewes pregnant with twins clinically resembled pregnancy toxaemia seen in field cases. A range of 3-5-4 d was necessary to induce these clinical signs. When offered feed at full rations after the period of feed withdrawal, ewes were reluctant to eat, although normal appetite returned within $2-3 \mathrm{~d}$. Some ewes showed a disinclination to move, as well as head pressing, often with teeth grinding. They became drowsy, with champing of the jaws, salivation, hindlimb ataxia and apparent blindness, with loss of the menace reflex. None of the ewes showed convulsions or coma. 
Table 2. Live weights $(\mathrm{kg})$ of control and ketotic ewes during late pregnancy and early lactation

(Mean values with their standard errors)

\begin{tabular}{|c|c|c|c|c|c|c|c|c|}
\hline & \multicolumn{4}{|c|}{ Control } & \multicolumn{4}{|c|}{ Ketotic } \\
\hline & $n$ & Mean & $\mathrm{SE}$ & $P^{*}$ & $n$ & Mean & SE & $P^{*}$ \\
\hline \multicolumn{9}{|c|}{ Day of pregnancy } \\
\hline 110 & 12 & 642 & $2 \cdot 7$ & $0 \cdot 14$ & 12 & $66 \cdot 3$ & $2 \cdot 5$ & 0.59 \\
\hline 130 & 12 & $68 \cdot 0$ & $2 \cdot 7$ & 0.60 & 12 & $70 \cdot 6$ & $2 \cdot 7$ & 0.099 \\
\hline 140 & 12 & $70 \cdot 0$ & $2 \cdot 7$ & & 12 & $64 \cdot 2$ & $2 \cdot 7$ & \\
\hline \multicolumn{9}{|c|}{ Day of lactation } \\
\hline 7 & 12 & $59 \cdot 9$ & $2 \cdot 7$ & 0.014 & 11 & $54 \cdot 9$ & $2 \cdot 5$ & 0.007 \\
\hline 28 & 12 & $57 \cdot 6$ & $2 \cdot 5$ & 0.003 & 11 & $56 \cdot 0$ & $2 \cdot 3$ & 0.011 \\
\hline
\end{tabular}

* Mean values for each group were compared with values at $140 \mathrm{~d}$ pregnancy by paired $t$ tests.

Table 3. Gestation length, lamb birth weights, placental weights and mortality data for twin-pregnant ewes with induced ketosis and control twin-pregnant ewes $\dagger$

(Mean values with their standard errors)

\begin{tabular}{|c|c|c|c|c|c|c|c|}
\hline & \multicolumn{3}{|c|}{ Control } & \multicolumn{3}{|c|}{ Ketotic } & \multirow{2}{*}{$\begin{array}{c}\text { Statistical } \\
\text { significance }\end{array}$} \\
\hline & $n$ & Mean & SE & $n$ & Mean & SE & \\
\hline Gestation length (d) & 12 & $150 \cdot 0$ & 0.40 & 12 & $142 \cdot 8$ & 0.70 & $* * *$ \\
\hline $\begin{array}{l}\text { Total lamb } \\
\text { birthweights }(\mathrm{kg}) \\
\text { (each ewe had twin } \\
\text { lambs) }\end{array}$ & - & $9 \cdot 4$ & $0 \cdot 14$ & 一 & $8 \cdot 3$ & 0.17 & $* *$ \\
\hline Placental weight (g) & 12 & $357 \cdot 0$ & $24 \cdot 70$ & 12 & $382 \cdot 0$ & 27.90 & $*$ \\
\hline \multicolumn{8}{|l|}{ Mortality data: } \\
\hline Ewes & - & - & - & & - & & \\
\hline Lambs & - & - & - & \multicolumn{4}{|c|}{$\begin{array}{l}\text { One ewe had one dead lamb } \\
\text { One ewe had a lamb which died } \\
\text { within } 2 \text { d of birth } \\
\text { Third ewe with dead twins } \$\end{array}$} \\
\hline
\end{tabular}

Statistical significance of difference between group means: ${ }^{*} P<0.05, * * P<0.01, * * * P<0.001$.

$\uparrow$ For details of procedures, see pp. 594-595.

† One ewe had dead twins and a severe metritis and so was withdrawn from the study.

The ewes recovered clinically within 3-4 $\mathrm{d}$ of refeeding after development of ketosis (mean 3.4 (SE 0.07) d), so that it was then possible to carry out further studies on the recovery of these ewes within a week of the development of clinical signs. In more severely affected ewes, complete clinical recovery did not occur until after they had lambed. It was necessary to treat three ewes with intravenous glucose, $100 \mathrm{ml} 500 \mathrm{~g}$ dextrose $/ 1$, and oral propylene glycol, $50 \mathrm{ml}$ twice daily, for several days as they failed to regain their appetites when feed was reintroduced. Treatment was successful within 1-2 d. These ewes were slow to come into milk compared with normal lactating controls.

In one ewe, one of the lambs was born dead, and in another the lambs were weak and one died within $2 \mathrm{~d}$ of birth, so that two ewes of the group initially reared one lamb, until 

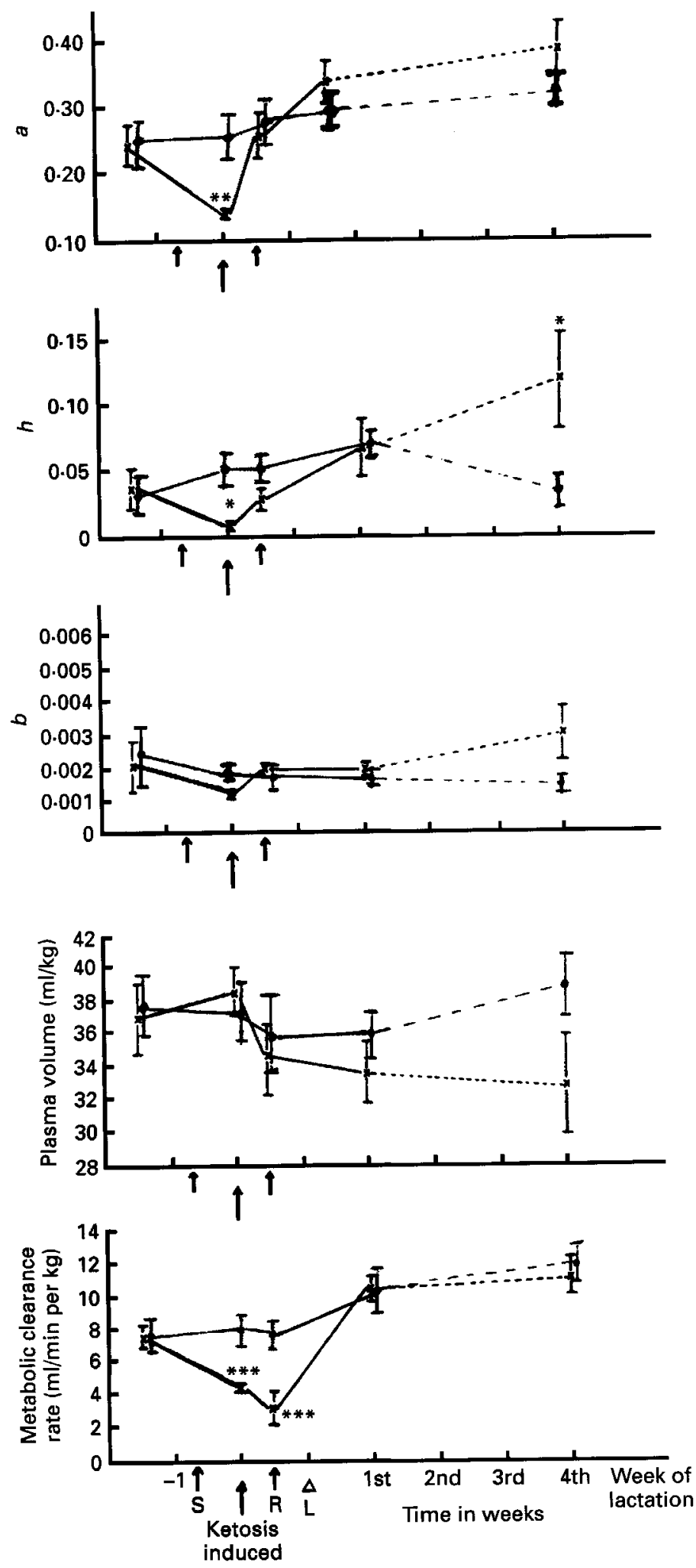

Fig. 2. For legend see facing page. 

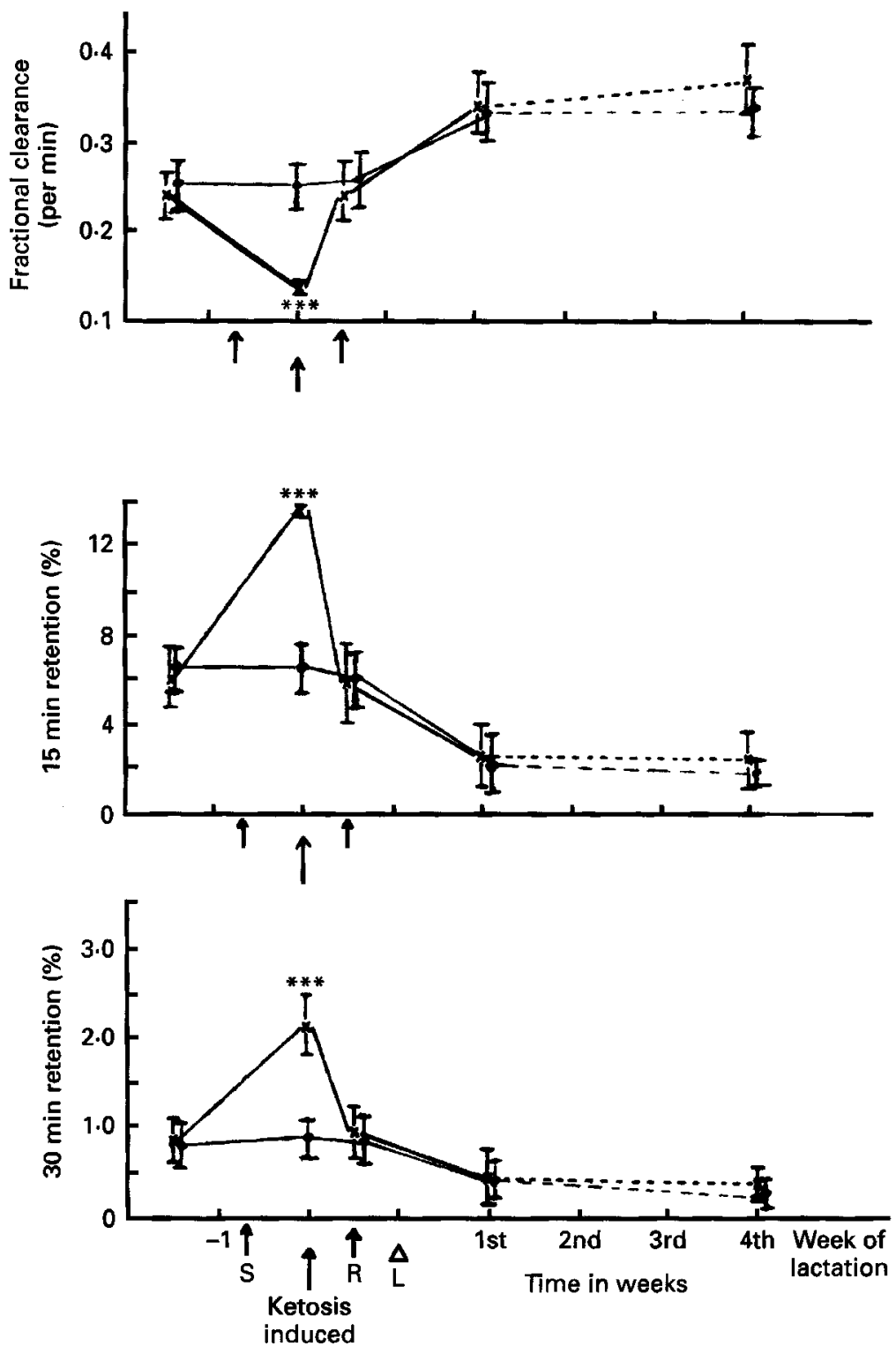

Fig. 2. Bromosulphthalein clearance data for ewes with induced ketosis $(x)$ and controls (O) during late pregnancy and on recovery from ketosis. Values are means with their standard errors indicated by vertical bars ( $n 11$ or 12). The start of induction of ketosis (S), clinical recovery from ketosis (R) and lambing $(L)$ are indicated on the horizontal axis. The proportionality transfer constants for hepatic uptake from plasma, $a$, biliary excretion, $h$, and transfer from liver back to plasma, $b$, are shown, together with plasma volume, metabolic clearance rate, fractional clearance and 15 and $30 \mathrm{~min}$ retentions. Results were compared with those from control ewes at the same stage of pregnancy and lactation by one-way ANOVA: ${ }^{*} P<0.05,{ }^{* *} P<0.01,{ }^{* * *} P<0.001$.

attempts to foster an additional lamb for each ewe were successful within $2 \mathrm{~d}$ of lambing (Table 3). A third ewe was withdrawn from the study, as she lambed dead twins and had a severe metritis and Actinomyces (Corynebacterium) pyogenes mastitis which responded well to treatment, although the lactation was less than expected. 


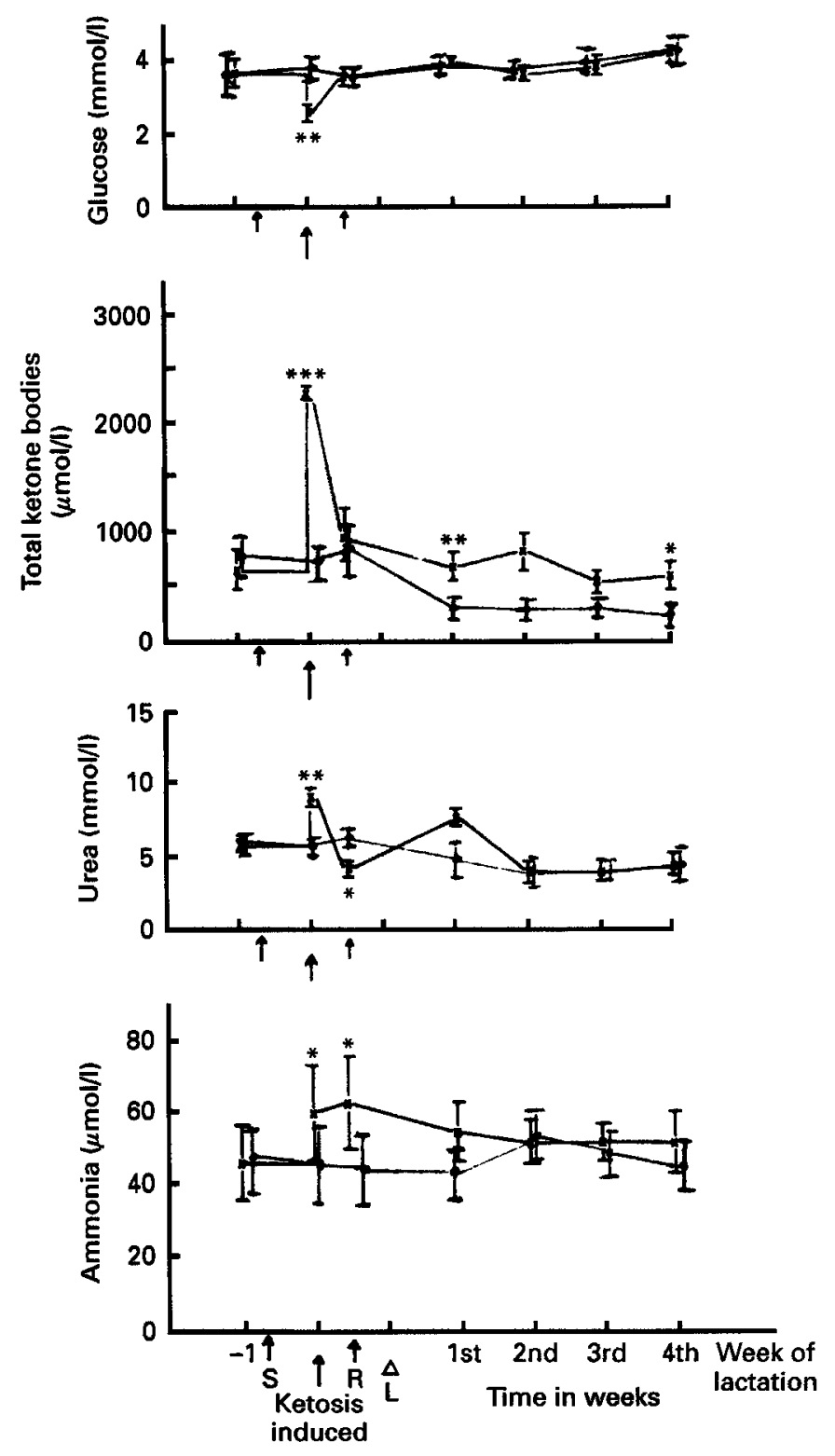

Fig. 3. Plasma glucose, total ketone-body, urea and ammonia concentrations in ewes with induced ketosis $(\times)$ during late pregnancy, recovery and early lactation and in controls (O). Values are means with their standard errors indicated by vertical bars ( $n 11$ or 12 ). The start of induction of ketosis (S), clinical recovery from ketosis $(\mathrm{R})$ and lambing $(\mathrm{L})$ are indicated on the horizontal axis. Results were compared with those from control ewes at the same stage of pregnancy and lactation by one-way ANOVA: ${ }^{*}<0.05, * * P<0.01, * * * P<0.001$.

\section{Bromosulphthalein clearance}

BSP was cleared in two phases by the livers of sheep following a single dose of $6 \mathrm{mg} \mathrm{BSP} / \mathrm{kg}$ intravenously. There was considerable individual variation in the shape of the BSP plasma disappearance graph in late pregnancy and early lactation in control ewes. In some, there 
was a marked 'flattening' of the plasma graph and dye was still present 60 min after injection. By comparison, BSP plasma clearance was reduced in ewes with induced ketosis. In ewes with induced ketosis, $a$ was significantly lower than in pregnant $(P<0.01)$ control ewes. They showed a gradual recovery with a return of $a$ to near normal during the first week of lactation (Fig. 2). The constant $h$ was significantly lower $(P<0.05)$ when ewes with induced ketosis were compared with pregnant control ewes. Values were returning to normal by the first week of lactation (Fig. 2). The constant $b$ was not significantly altered during the clinical signs of induced ketosis and the recovery stage.

During pregnancy the $h: b$ ratio fell but $h$ was never less than $b$. No significant effect on $b$ was demonstrated because of pregnancy or lactation in healthy control ewes. The excretory function of the liver returned to normal soon after lambing (Fig. 2).

In ewes with induced ketosis, the plasma volume fell during recovery (Fig. 2) but not significantly compared with healthy ewes.

The metabolic clearance rate in ewes with induced ketosis and at recovery was significantly lower than in control ewes $(P<0.001)$. There was a return of the metabolic clearance rate to normal by the first week of lactation in ewes with induced ketosis, reflecting comparable increases in hepatic blood flow. BSP fractional clearance declined on induction of ketosis while 15 and $30 \mathrm{~min}$ retention increased $(P<0.001)$. These gradually returned to normal on recovery and during lactation (Fig. 2), reaching values comparable with those in healthy ewes by the first week of lactation.

\section{Clinical chemistry}

Fig. 3 shows that on induction of ketosis, plasma glucose concentrations fell while total ketone-body, urea and $\mathrm{NH}_{3}$ concentrations rose. The changes in glucose $(P<0.01)$, total ketone-body $(P<0.001)$, urea $(P<0.001)$ and $\mathrm{NH}_{3}(P<0.05)$ concentrations were significantly different when compared with normal pregnant ewes. These concentrations returned to normal by the first week of lactation, although total ketone bodies were still higher, but fluctuating, than in normal lactating ewes by the fourth week of lactation.

\section{DISCUSSION}

\section{Live weight and condition score}

A condition score of 3.5 is average in Lowland housed ewes at $110 \mathrm{~d}$ gestation (Clarkson $\&$ Faull, 1990). The period of feed withdrawal from $132 \mathrm{~d}$ gestation resulted in significant weight loss and loss of condition score (Tables 1 and 2) of the ketotic ewes, which is to be expected (Holst et al. 1986). The rapid recovery of appetite once feed was freely available was at variance with the response of field cases of pregnancy toxaemia (Kronfeld, 1972).

\section{Gestation period and induction of ketosis}

A significant reduction in the gestation period in twin-pregnant sheep $(P<0.001)$ concurred with the observations of Ranaweera et al. (1979) in induced ketosis in ewes. Three ketotic ewes had dead or weak lambs and required treatment as they failed to recover spontaneously (Table 3). A number of studies (Mellor, 1983; Nordby et al. 1986) have reported maternal undernutrition causing a decrease in birth weight of the lamb, but this varies with the period of gestation (Faichney \& White, 1987). This may be because the mobilization of maternal body tissue and the shift in factors regulating partition of nutrients by the dam are able to buffer growth of the fetus particularly from short periods of feed deprivation (Holst et al. 1986). The lower birth weight of lambs in ewes with induced ketosis (Table 3) was expected from field observations in ewes with pregnancy toxaemia 
(Wierda et al. 1985) but there have been no reports of induction of ketosis in twin-pregnant ewes. McCrabb et al. (1991) showed that variability in fetal weight was not determined by placental weight alone in ewes at the 140 th day of pregnancy.

Impaired carbohydrate and volatile fatty acid metabolism is responsible for pregnancy toxaemia in ewes, resulting in an inability to meet the energy demands for production of milk or lambs. In the present study the clinical signs of induced ketosis resembled those of field cases (pregnancy toxaemia). The production of dead or weak lambs that died soon after birth followed by recovery of the ewe and slow onset of lactation is more pronounced in field cases (Kronfeld, 1972; Wierda et al. 1985), which often have a higher maternal mortality rate.

The increased placental weight (Table 3 ) in ewes with induced ketosis compared with controls $(P<0.05)$ was to be expected, although placental growth is more affected by maternal undernutrition in mid-pregnancy (McCrabb et al. 1991), while decreased lamb birth weight is more likely to be observed in the last trimester of pregnancy, especially for twins (Mellor, 1983; Holst et al. 1986), because of the placental limit on the supply of nutrients, especially glucose. The effects of undernutrition on placental weight vary with stage of gestation (Mellor, 1983; Faichney \& White, 1987; McCrabb et al. 1991), and like lamb weight, are less affected by short periods of feed deprivation (Holst et al. 1986). In the present study, placental weight was determined in intact ewes accounting for variation in absolute values between studies (McCrabb et al. 1991). Even so, placental weight is expected to vary widely between individual ewes (Mellor, 1983). The survival of the fetus is influenced more by a small placenta than by maternal underfeeding (Mellor, 1983) and premature birth is a feature of both. Reid (1968) drew attention to the disagreement among some workers as to the effectiveness of inducing clinical signs of pregnancy toxaemia in ewes with twin pregnancies at 130 or more days of pregnancy. He felt that the syndrome mimicked naturally occurring cases once hypoglycaemia was severe and the concentration of blood ketones had reached $1900 \mu \mathrm{mol} / 1$ and the work of Katz \& Bergman (1966), and Ford et al. (1990) supported this. The ewes in the present study satisfy their criteria for induction of ketosis (pregnancy toxaemia). The treatment of the three ewes in the present study which failed to recovery spontaneously was in accordance with the recommendations of Patterson \& Cunningham (1969).

\section{Bromosulphthalein plasma clearance}

The BSP test was sensitive and reflected changes in the normal physiological state of the liver during multiple pregnancies and lactation. BSP is an organic anion and measures hepatic function i.e. uptake, conjugation and excretion, at the cellular level (Fig. 1) which is compromised in normal sheep in late gestation with changes being more pronounced in induced ketosis. The proportionality transfer constants provided more detailed information on hepatic function at the cellular level, and the metabolic clearance rate was a very sensitive test. The fractional clearance and 15 and $30 \mathrm{~min}$ retentions were also sensitive to altered hepatic function.

The significant reduction in the proportionality transfer constant $a$ during pregnancy and induced ketosis was probably due to circulatory changes altering hepatic cellular uptake. The rate of elimination of BSP into bile, $h$ was also altered but not $b$, the rate of reflux into plasma. The extent of these changes is most likely to be related to the degree of fatty infiltration of the liver that occurs during late pregnancy in normal healthy ewes carrying twin lambs (Katz \& Bergman, 1966) and which is reversible. This is borne out by the return of these values to normal soon after lambing in normal pregnancies and on recovery from induced ketosis (Fig. 2), suggesting that these changes are physiological and reversible. If this process continues in ewes in late pregnancy, the fatty infiltration becomes excessive, 
resulting in pregnancy toxaemia (Procus \& Gilchrist, 1966), the condition resembling preeclampsia in women.

Tindall \& Beazley (1965) and Beazley \& Tindall (1966) placed considerable importance on the value of measuring the excretory efficiency of the liver $(h /[b+h]) \%$, i.e. the proportion of dye which leaves the liver cells in healthy pregnant women. In the present study there was very little change in this value, i.e. the equivalent values were $97 \%$ for nonpregnant, $95 \%$ for pregnant and $96 \%$ for lactating ewes when the means were compared. This is because $b$ is small in sheep; however, it would appear that there are species variations in pregnancy in the handling of BSP by the liver and the number of fetuses has an effect. Tindall \& Beazley (1965) suggested that during pregnancy increased circulating oestrogens may reduce the available binding sites for BSP in the liver causing a reduction in the amount and rate of elimination of dye into bile and greater return of unbound dye from hepatic cells to plasma. There was no transfer of BSP across the placenta in pregnant women, no BSP metabolites in plasma, and negligible urinary loss of BSP given by single injection, but the relative storage space was greater in twin than in single pregnancies.

The large plasma volume in healthy pregnant and lactating ewes was probably caused by an increase in extracellular fluid space and has been previously described in ewes during gestation continuing into lactation (MacFarlane et al. 1959).

The reduction in metabolic clearance rate in ketotic ewes $(P<0.001)$ was probably caused by fatty infiltration of the liver at this time and the biochemical changes associated with cellular necrosis. As the liver recovered, these values returned gradually to normal during lactation. Some of this may be an effect on hepatic blood flow which may be due to reduced food intake (Reid \& Collins, 1980) rather than to fatty liver per se. During pregnancy the proportion of blood flowing to the liver is expected to fall as blood flow to the uterus and kidneys increases. However, Bergman et al. (1970) showed considerable individual variability in liver blood flow values in twin-pregnant fed sheep. It is difficult to separate these changes as ewes with natural cases of pregnancy toxaemia voluntarily restrict their feed intake as the signs worsen.

In the present study the ewes with induced ketosis had 13.9 (SE 1.06)\% BSP retention at $15 \mathrm{~min}$ and all recovered, which concurs with the observations of Cornelius et al. (1958). Some of the interindividual variation in ewes in the present study may have been because the change in weight of the ewes was variable over the study period.

\section{Clinical chemistry}

Plasma glucose concentrations were inversely proportional to the degree of ketonaemia, a point also mentioned by Bergman \& Kon (1964) (Fig. 3). The return of the blood glucose, ketone-body and urea concentrations to normal on recovery was anticipated. Uraemia is considered a terminal change (Katz \& Bergman, 1966; Wierda et al. 1985). The laboratory results were related to the severity of the clinical signs reported. The condition of induced ketosis was reversible in all ewes and did not progress to coma with build-up of acetoacetate, which can lead to irreversible hypoglycaemic encephalopathy, ketoacidosis and uraemia (Wierda et al. 1985). The condition with a fatal outcome might have produced more marked changes in laboratory findings.

In conclusion, the more severe clinical condition of pregnancy toxaemia in naturally occurring cases suggests that factors other than undernutrition may be contributory, including the general body condition of the ewe and the metabolism of glucose by the liver, involving the conversion of propionate to glucose.

The author wishes to acknowledge the assistance of the late Professor E. J. H. Ford for the use of the sheep on which this study was undertaken and for setting up the protocol. $\mathrm{Mr}$ 
G. Hynes assisted with some of the bromosulphthalein and clinical chemistry measurements and $\mathrm{Mr} \mathrm{D}$. Horne was responsible for the care and handling of the sheep.

\section{REFERENCES}

Bakker, N. \& White, R. R. (1957). A simplified micro-method for the colorimetric determination of total acetone bodies in blood. New Zealand Journal of Science and Technology 38, 1001-1008.

Beazley, J. M. \& Tindall, V. R. (1966). Changes in liver function during multiple pregnancy using a modified bromosulphthalein test. Journal of Obstetrics and Gynaecology 73, 658-661.

Bergman, E. N., Katz, M. L. \& Kaufman, C. F. (1970). Quantitative aspects of hepatic and portal glucose metabolism and turnover in sheep. American Journal of Physiology 219, 785-793.

Bergman, E. N. \& Kon, K. (1964). Acetoacetate turnover and oxidation rates in ovine pregnancy ketosis. American Journal of Physiology 206, 449-452.

Bergman, E. N., Roe, E. R. \& Kon, K. (1966). Quantitative aspects of propionate metabolism and gluconeogenesis in sheep. American Journal of Physiology 211, 793-799.

Clarkson, M. J. \& Faull, W. B. (1990). A Handbook for the Sheep Clinician, 4th ed., pp. 15 and 23-24. Liverpool: Liverpool University Press.

Cornelius, C. E., Holm, L. W. \& Jasper, D. E. (1958). Bromsulphthalein clearance in normal sheep and in pregnancy toxaemia. Cornell Veterinarian 48, 305-312.

Da Fonseca-Wollheim, V. F. (1973). Direkte Plasma Ammonia-bestimmung ohne Enteiweibung (Determination of plasma ammonia concentration). Journal of Clinical Chemistry and Clinical Biochemistry 11, 426-430.

Demigné, C., Yacoub, C., Morand, C. \& Rémésy, C. (1991). Interactions between propionate and amino acid metabolism in isolated sheep hepatocytes. British Journal of Nutrition 65, 301-317.

Faichney, G. J. \& White, G. A. (1987). Effects of maternal nutritional status on fetal and placental growth and on fetal urea synthesis in sheep. Australian Journal of Biological Science 40, 365-377.

Fawcett, J. K. \& Scott, J. E. (1960). A rapid and precise method for the determination of urea. Journal of Clinical Pathology 13, 156-159.

Ford, E. J. H. \& Boyd, J. W. (1960). Some observations on bovine acetonaemia. Research in Veterinary Science $1,232-241$

Ford, E. J. H., Evans, J. \& Robinson, I. (1990). Cortisol in pregnancy toxaemia of sheep. British Veterinary Journal 146, 539-542.

Holst, P. J., Killeen, I. D. \& Cullis, B. R. (1986). Nutrition of the pregnant ewe and its effect on gestation length, lamb birth weight and lamb survival. Australian Journal of Agricultural Research 37, 647-655.

Katz, M. L. \& Bergman, E. N. (1966). Acid bases and electrolyte equilibrium in ovine pregnancy ketosis. American Journal of Veterinary Research 27, 1285-1292.

Krebs, H. A. (1966). Bovine ketosis. Veterinary Record 78, 187-192.

Kronfeld, D. S. (1972). Ketosis in pregnant sheep and lactating cows. Australian Veterinary Journal 48, 680-687.

Lemons, J. A., Adcock, E. W., Jones, M. W., Naughton, M. A., Meschia, G. \& Battaglia, F. C. (1976). Umbilical uptake of amino acids in the unstressed fetal lamb. Journal of Clinical Investigation 58, 1428-1434.

McCrabb, G. J., Egan, A. R. \& Hosking, B. J. (1991). Maternal undernutrition during mid-pregnancy in sheep. Placental size and its relationship to calcium transfer during late pregnancy. British Journal of Nutrition 65, 157-168.

MacFarlane, W. V., Morris, R. J. H., Howard, B. \& Budtz-Olsen, O. E. (1959). Extracellular fluid distribution in tropical Merino sheep. Australian Journal of Agricultural Research 10, 271-286.

Mellor, D. G. (1983). Nutritional and placental determinants of foetal growth rate in sheep and consequences for the newborn lamb. British Veterinary Journal 139, 307-324.

Ministry of Agriculture, Fisheries and Food (1984). Energy Allowances and Feeding Systems for Ruminants. Reference Book no. 433. London: H.M. Stationery Office.

Morley, G., Dawson, A. \& Marks, V. (1968). Manual and autoanalyser methods for measuring blood glucose using guaicum and glucose oxidase. Proceedings of the Association of Clinical Biochemistry 5, 42-45.

Nie, N. H. (1983). SPSSX User's Guide (A Complete Guide to SPSSX Language and Operations). New York: McGraw-Hill Book Company.

Nordby, D. J., Field, R. A., Riley, M. L., Johnson, C. L. \& Kercher, C. J. (1986). Effects of maternal undernutrition during early pregnancy on postnatal growth in lambs. Proceedings (Western Section) American Society of Animal Science 37, 92-95.

Patterson, D. S. P. \& Cunningham, N. F. (1969). Metabolic and hormonal aspects of bovine ketosis and pregnancy toxaemia in the ewe. Proceedings of the Nutrition Society 28, 171-176.

Procus, J. \& Gilchrist, F. M. C. (1966). Ovine ketosis. Journal of Veterinary Research 33, 161-165.

Ranaweera, A., Ford, E. J. H. \& Samad, A. R. (1979). The effect of triamcinolone acetonide on plasma glucose and ketone concentration and on the total entry rate of glucose in twin pregnant hypoglycaemic ketotic sheep. Research in Veterinary Science 26, 12-16.

Rattenbury, J. M., Kenwright, A. M., Withers, C. J. \& Shepherd, D. A. L. (1983). Effects of propionic acid on urea synthesis by sheep liver. Research in Veterinary Science 35, 61-63. 
Reid, I. M. \& Collins, R. A. (1980). The pathology of postparturient fatty liver in high-yielding dairy cows. Investigative Cellular Pathology 3, 237-249.

Reid, R. L. (1968). The physiopathology of undernourishment in pregnant sheep with particular reference to pregnancy toxaemia. Advances in Veterinary Science 12, 163-238.

Stacey, T. E., Weedon, A. P., Haworth, C. \& Ward, R. H. T. (1978). Feto-maternal transfer of glucose analogues by sheep placenta. Annales de Recherches Vétérinaires 8, 345-352.

Tindall, V. R. \& Beazley, J. M. (1965). An assessment of changes in liver function during normal pregnancy using a modified bromosulphthalein test. Journal of Obstetrics and Gynaecology 72, 717-737.

West, H. J. (1989). Clearance of bromosulphthalein by the liver of sheep. Research in Veterinary Science 46 , 258-263.

Wierda, A., Verhoeff, J., Dorresteign, H., Van Dyk, S. \& Wensing, T. (1985). Effects of trenbolone acetate and propylene glycol on pregnancy toxaemia in ewes. Veterinary Record 116, 284-287. 